\title{
MARKETING LOGISTICS
}

\author{
Ryszard Barcik $^{1}$, Marcin Jakubiec ${ }^{2}$ \\ ${ }^{1}$ University of Bielsko-Biała, Faculty of Management and Computer Sciences, Ul. Willowa 2, 43-309 \\ Bielsko-Biała, Poland \\ Email:rbarcik@ath.bielsko.pl \\ ${ }^{2}$ University of Bielsko-Biata, Faculty of Management and Computer Sciences, Ul. Willowa 2, 43-309 \\ Bielsko-Biała, Poland \\ Email:m.jakubiec@ath.bielsko.pl
}

\begin{abstract}
In the paper authors showed actual topic concerning connection between marketing and logistics and their spheres. The paper is divided into four main paragraphs which include: good's distribution and marketing instruments, logistics and marketing, marketing logistics and logisticmarketing management. Marketing could not exist without logistics and logistics could not exist without marketing - this main point authors tried to improve in following papers. All positive and negative factors of relation between marketing and logistics were shown. This relation created modern management - logistic-marketing management.
\end{abstract}

Keywords: distribution, marketing, marketing instruments, marketing logistics, 7P formula.

JEL classification: L11, M31

Doručeno redakci: 16.12.2010; Recenzováno: 2.3.2011; 18.4.2013; Schváleno k publikování: 11.9.2013

\section{Introduction}

A sign of coherence of logistics and marketing is a concept called marketing logistics. Marketing logistics is described as a system of planning and acting which guarantees that ordered goods will be supplied on time, with using of proper means of transport, in the quickest way and possibly the cheapest, Dwiliński (1998). Taking of logistic activities in cooperation with marketing happens in area of point of contact which is logistics in delivery and distribution, creating commonly a structure of marketing logistics.

\section{Goods distribution and marketing instruments}

Decisions making in distribution area must be primarily in accordance with decision making in the product area. They decide about the form of distribution channels, which involve not only a way of products' delivering to stores, but also a choice of stores' type, their location and forms of sales, which influences a way of products delivering to consumers. The type of products, their structure and all detailed features determine likely solutions of distribution hardships. Possession of stores' net by a company with an exact location and forms of sales or an access to the net often affects forming of product features and other marketing instruments.

Connections between goods distribution and sales activation are also noticeable. They exist primarily between the type of the distribution channel and intensiveness of usage of activation sales means, e.g. a manufacturing company could make a conclusion that more profitable are sales directly to retailers or even to consumers, because a wholesaler is not engaged in supporting of sales of producer's products, even if this method is more expensive. If indirect and longer distribution channels are used, more attention must be devoted to a problem of customers' interest in a producer using intensive and direct commercials.

Goods sales by many co-salesmen acting on differ levels of distribution channels require an active influence of a producer on these co-salesmen. It is up to date in the example of these 
mediating companies, whose motivation is not compatible with motivation of producer's acting. With regard to the mentioned above, a program of producer's influence on cosalesmen should take into account not only a part of long-term policy of maintaining good relations with them, but also instruments used in actual stimulating. It could require enhancing of some forms of promotion to co-salesmen (e.g. salesmen's promotion), advertisement or active forms of personal sales (e.g. a group of agents keeping in touch with co-salesmen). Difficulties or impossibilities of enhancing these means persuade to choose such channels, which do not need to use these means, Lichtarski (1999).

Simultaneousness of being and correlation of marketing-mix instruments bring about that distribution must be adjusted to other instruments and change with them. The type, the price and the phase of product life determine intensiveness of its placing on a market, and a growth could require a change of distribution channel, on one side. On the other side, distribution as an element of a marketing program characterizes a relatively small elasticity different from other marketing instrument. Firstly, it derives from material-technical factors. Their changes with respect to limited mobility of these factors demand frequent new investments, e.g. a way of advertising of goods could be changed quickly, in opposition to a way of their offering that requires longer time. Secondly, parts of distribution are not changeable depending of manufacturing company, ensuring a proper way of goods offering to consumers needs longterm influence on co-salesmen. Using of distribution instruments is not an internal case of a company, but demands the establishment of contacts with other companies. From the development of distribution instruments relays whether decisions of their utilization would be made in advance or how often other marketing instruments would be adjusted to distribution parts. It could be seen that goods distribution is formed not only by taking under consideration the needs and aspirations of consumers, but also by taking into account other marketing instruments, Lichtarski (1999).

Goods distribution is only then an element of marketing, when commonly with other instruments creates an integrated complex of made decisions in the sphere of customers' service. It is also worth mentioning, that strategic problems of distribution are situated on a contact of logistics and marketing, Kotler, (1998).

Figure 1 shows connection between distribution and logistics.

\section{Logistics and marketing}

Recently logistics and marketing have been treated in companies as separate areas. The reasons of that fact were the following, Pilarczyk, Mruk, Sojkin, Szulce (1999):

- traditional treatment and mechanical division of marketing and logistics function, but meaning of logistics in gaining and maintaining of competitive edge was small (logistics was treated and organized as a transportation and warehousing department),

- showing off a role of logistic costs from the point of view of a growth of company effectiveness and success (cost approach was against marketing market orientation, which caused separation of marketing and logistics),

- underestimation in practice of goods physical route management and its information conditions in aspect of integrated marketing management (not long ago marketing management was restricted to product's strategy, price and promotion; rarely a marketing department was responsible for all aspects of integrated management in the sphere of distribution and delivery with conscious logistics including). 
Figure 1: Connection between marketing and logistics

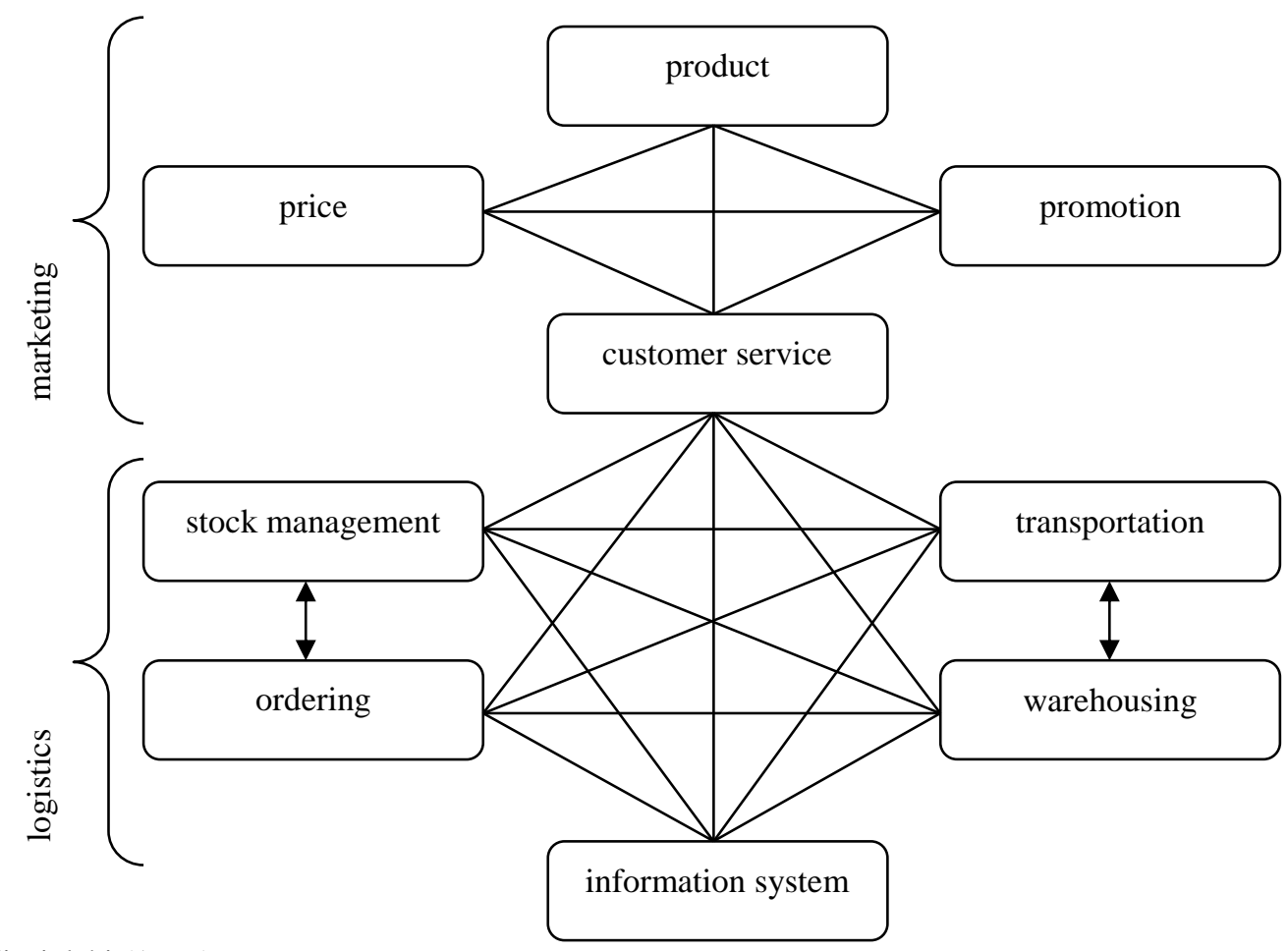

Source: Ciesielski (1999).

In the 80s, there could be noticeable an intensive growth of marketing and logistics as separate development and evolution tendencies (it means a change from treating them as functions in a company used to much extended management concepts, creating simultaneously much potential and real circumstances and areas for integration. On one side, the growth of marketing was taking place towards market oriented management in a company, on the other side, the growth and development of logistics as sectional oriented, penetrating a whole company, an integrated management concept of goods and information flow).

Integration in operational spheres, strategic and even normative decisions in logistics and marketing system and a company, reflecting a real position and adjustment of logistics and marketing in an organization and a management structure of a company (competences integration), enabling its effective orientation to the future, long-term activities and the use of potentials of effectiveness and a company success could be noticeable later.

Companies have started to notice that effective logistics is the crucial part of marketing strategy enabling to get competitive edge.

Fundamental occurrences and reasons bringing about a need of integration process between logistics and marketing and supporting this process could be, Pilarczyk, Mruk, Sojkin, Szulce (1999):

- a growth of market differentiation (differentiation of customers' needs and preferences, individualization of market segments, products' diversification, etc.),

- growing competition in scope of a level and quality of services and customer service (a growth of demands in scope of additional benefits and usefulness connected with purchasing and sales of goods),

- a shorter product life-cycle, 
— tendencies related to concentration in trade, creating and developing of new distribution channels,

— integration of economic processes and decisive processes (using of synergy in micro macro scale),

- a growth of new technology in the sphere of goods and information flow, promotion, sales, etc.,

- a growth of entrepreneurship and innovativeness in market and economic activities,

— integration and globalization of markets.

Marketing and logistics are similar because they both attend in an adjusting process of structure and dimension of supply to customers' needs and wants. They are also complementary - marketing stimulates demand, logistics satisfies it by distribution processes, Blaik (2001).

Marketing embraces all activities and instruments which have direct purpose recognition, specification and a creation of market effects potentials and company success. Logistics is geared towards the creation and usage of effectiveness potentials and the system supporting a company market orientation. Integration of logistics is oriented to the growth of customers' services.

Both approaches give a possibility of an effective use of potentials and skills, which contribute to the achievement of a required service level and long-term customers' satisfaction and loyalty, as well as a proper amount of profit in the strategic dimension. During a strategy preparing, it must be taken into account, that long-term and complex creating and using of marketing and logistics potentials and skills could let to simultaneous achievement and common support mentioned above logistics and marketing goals in scope of general company purposes.

\section{Marketing logistics}

The service of deliveries and logistic services for clients, as a multidimensional logistics effect, occupies a central place among other marketing instruments. Commonly with such instruments like product's policy, price and promotion, logistics is used — in the framework of marketing strategy - to achieve the highest level of quality of customers' satisfaction and their fulfillment from trade contacts, Pilarczyk, Mruk, Sojkin, Szulce (1999) (figure 2).

Customer satisfaction also includes maximization of place and time usefulness, Rutkowski (2000). Place usefulness could be described as a created or added value to a product by possibility of buying and consuming it in a proper place. Logistics is directly responsible for adding of place usefulness to a product, because on it the effectiveness of moving of raw materials and materials for production and products from a manufacturing place to a sales place depends. Time usefulness is a value created by making a product accessible in proper time. Logistic activities aim to add place and time usefulness to a product. Buyers companies need a proper amount of raw materials and components directly before starting of a production process. Necessary, defined level of stocks of a recipient should be maintained by realization of present, synchronized with production schedule deliveries. Uncertainty related to deliveries of these raw materials could cause disturbance of production rhythm and show a company in a bad light for clients and competitive environment.

Combination of logistic instruments with marketing concept of influencing market could be a starting point to form proposals of a better, improved product by adding new values for 
clients. These proposals might be e.g. planning and introducing of logistic systems, maintaining of constant internal transport or after sales service (fig. 3).

Tasks of marketing logistics are as follows, Garbarski, Rutkowski, Wrzosek (2000):

— choosing of places for exhibitions and displays and showing product's functional-useful features,

- creating proper conditions for displays (tracks, lights, rotating platforms, company gadgets, screens and equipment for multimedia, posters, seats for audiences, sanitation, etc.),

- supplying a necessary amount of products (with needed features),

— taking on qualified employees and ensuring them proper conditions,

- realization of potential customer service,

- assessment of exhibition in terms of logistic processes and making conclusions letting improve such activities in the future.

Figure 2: Marketing logistics in system of marketing and logistics (general approach)

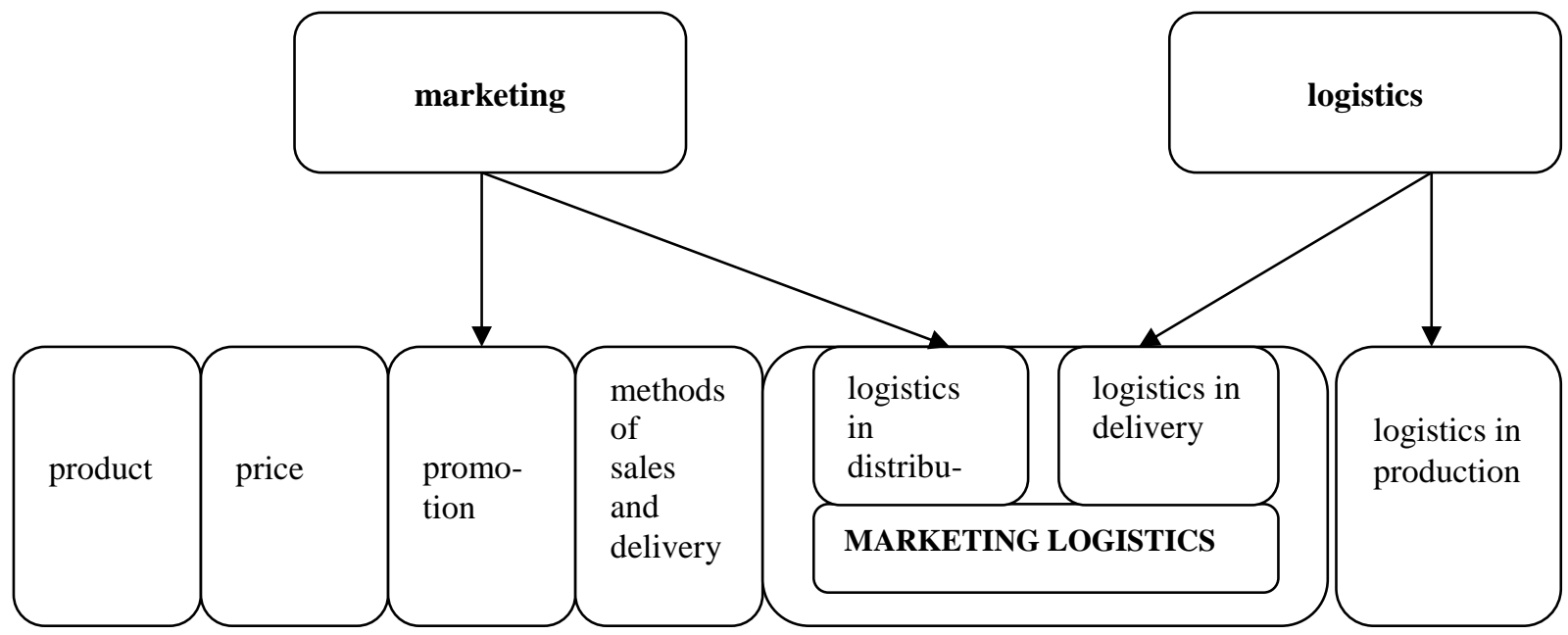

Source: Blaik (2001).

\section{Logistic-marketing management}

Integration of different processes and logistic functions in the framework of logistic system and logistic management, as well as integration of this system with marketing system in scale of a company and market is reflected in an integrated concept of logistic-marketing management, constituting fundamental aspect of modern company management.

Logistic-marketing management constitutes linkage and integration of two concepts, on one side - logistics as a management concept oriented on flows, and - marketing as a concept oriented on company management, on the other. Both mentioned management concepts meet on very fragile ground which is market, determining a strategy of company's acting on delivery and distribution market, Pilarczyk, Mruk, Sojkin, Szulce (1999). Present logistics and marketing are treated as dual concepts of integrated company management.

Logistics and marketing are defined as main orientations (criteria) of management in a company and interpreted in the real sense as significant (equivalent) spheres of functional and integrated processes in company. Preparing a strategy of a company, special attention should be paid to the relation between logistic and marketing strategies. If marketing is identified 
with strategic management, then logistics is a part of it. In a modern company marketing must be logistic, logistics must be marketing, Kotler (1998).

In the modern concept of logistic-marketing management on one side, customer satisfaction is achieved by coordinated marketing activities concerning product, price, promotion and distribution by offering to customer by logistics time and place usefulness. On the other side, achieving by company an acceptable level of profit in long time is determined by reduction of global logistic costs.

An effect of strategic logistic activity is a group of values and benefits achieved by customer. It is described as "7P" formula of logistic activity: proper product, proper information, proper amount, proper quality, proper time, proper place, proper cost of order, Pilarczyk, Mruk, Sojkin, Szulce (1999).

Figure 3: Cooperation of marketing and marketing logistics

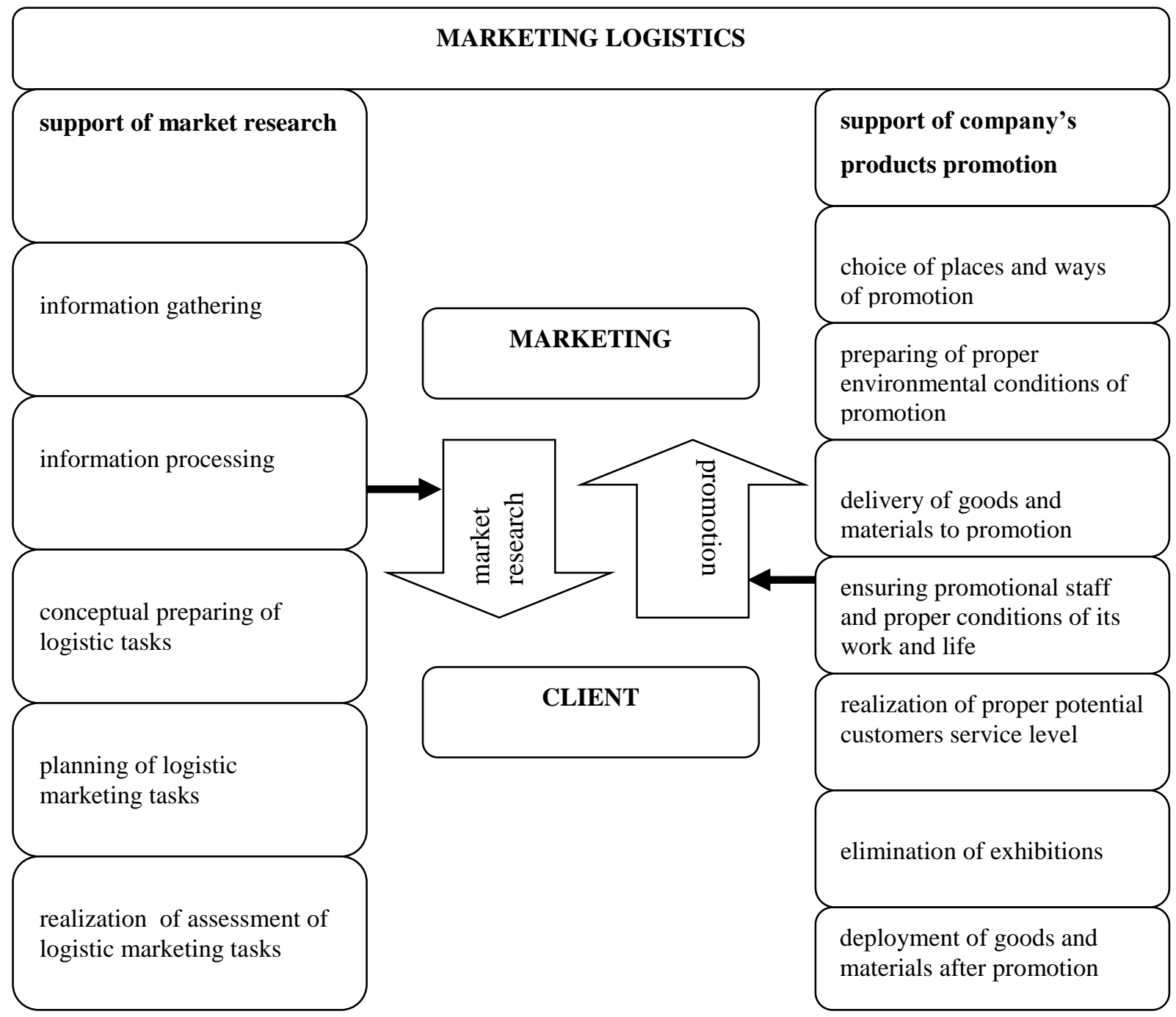

Source: Dwiliński (1998).

Commonly with such marketing instruments and programs like product policy, price policy, promotion and sales policy (marketing-mix), logistics-mix (transportation, warehousing, 
stocks, packaging, orders' realization and service) is used to achieve the highest level of customer's wants and needs satisfaction.

\section{Conclusion}

For strategic level of management in a company possessing of information from marketing and logistic area is vitally important, ensuring a wide glance at problems relating to company functioning. Marketing and logistic data collected on company's needs could come from diverse sources: internal and external.

External data come from marketing-logistic research and environment monitoring. The research could involve collecting data from primary and secondary sources. Using of primary data is collecting information for the first time based on research needs, using of secondary data means using collected data.

Using of primary data could concern, Tarondeau, Xarder (1999):

- product quality and logistic service measure,

— assessing of distribution systems functioning, their reliability and flexibility,

— location of distribution centers, sales points - product availability and costs assessments.

Combining conclusions from the data analysis and information from internal and external sources gives a full picture of the situation. For collecting and preparing of data marketing logistics and distribution logistics departments are responsible. Tasks of marketing logistics departments are concentrated around preparing of exhibitions, displays and other events, which could promote product in an information aspect. They should have warehouse for materials used during these parties.

Distribution logistics department assists in collecting and preparing of information from: orders, sales, service and guarantee service. Such information is used in: planning of production, goods distribution, spare parts, etc. Information should be also analyzed in the marketing aspect, because it could give suggestions for assessments, Garbarski, Rutkowski, Wrzosek (2000):

- changes of demand on product's types,

- changes of customers' preferences,

- expectations in scope of customer service level improving.

\section{References}

[1] ABT, S. and K. RICHTER, 2000: Logistyka ponad granicami, Wyd. ILiM, Poznań.

[2] ALTKORN, J., 1998: Podstawy marketingu, praca zbiorowa, Instytut Marketingu, Kraków.

[3] ALTKORN, J. and T. KRAMER, 1998: Leksykon marketingu, PWE, Warszawa.

[4] BLAIK, P., 2001: Logistyka. Koncepcja zintegrowanego zarządzania, wyd. II, PWE, Warszawa.

[5] CIESIELSKI, M., 1999: Logistyka w strategiach firm, PWN, Poznań.

[6] DĘBSKI, S., 1998: Ekonomika i organizacja przedsiębiorstw, Wydawnictwo Szkolne i Pedagogiczne, Warszawa.

[7] DWILIŃSKI, L., 1998: Wstęp do logistyki, Oficyna Wydawnicza PW, Warszawa. 
[8] GARBARSKI, L., I. RUTKOWSKI and W. WRZOSEK, 2000: Marketing. Punkt zwrotny nowoczesnej firmy, PWE, Warszawa.

[9] KOTLER, P., 1998: Marketing. Analiza, planowanie, wdrażanie i kontrola, Wyd. Gebethner \& Spółka, Warszawa.

[10] LICHTARSKI, J., 1999: Podstawy nauki o przedsiębiorstwie, Wydawnictwo Akademii Ekonomicznej, Wrocław.

[11] MICHALKIEWICZ, J., 2/2001: Strategiczny alians marketingu i logistyki, w: Marketing w praktyce.

[12] PENC, J., 1998: Leksykon biznesu, Agencja Wydawnicza "Placet", Warszawa.

[13] PILARCZYK, B., H. MRUK, B. SOJKIN and H. SZULCE, 1999: Podstawy marketingu, Wydawnictwo Akademii Ekonomicznej, Poznań.

[14] PRZYBYŁOWSKI, K., S. W. HARTLEY, R. A. KERIN and W. RUDELIUS, 1998: Marketing, Dom Wydawniczy ABC, Warszawa.

[15] RADZIEJOWSKA, G., 2000: Logistyka w przedsiębiorstwie, Wyd. Politechniki Śląskiej, Gliwice.

[16] RUTKOWSKI, K., 2000: Logistyka dystrybucji, praca zbiorowa, Difin, Warszawa.

[17] SKOWRONEK, CZ. and Z. SARIUSZ-WOLSKI, 1999: Logistyka w przedsiębiorstwie, PWE, Warszawa.

[18] SZTUCKI, T., 1998: Marketing przedsiębiorcy i menedżera, Agencja Wydawnicza Placet, Warszawa.

[19] TARONDEAU, J. C. and D. XARDER, 1999: Dystrybucja, Assimiel Polska, Kraków. 